\author{
Monika Maria Cysek-Pawlak \\ https://orcid.org/0000-0002-8175-6779 \\ Łódź University of Technology, Faculty of Civil Engineering \\ Architecture and Environmental Engineering, Institute of Architecture and Urban Planning \\ monika.cysek@p.lodz.pl \\ Tomasz Krystkowski \\ https:// orcid.org/0000-0002-5619-2457 \\ Łódź University of Technology, Faculty of Civil Engineering \\ Architecture and Environmental Engineering, Institute of Architecture and Urban Planning \\ tomasz.krystkowski@p.lodz.pl \\ Jakub Misiak \\ https:// orcid.org/0000-0003-2843-8752 \\ Interdisciplinary Doctoral School \\ jkb.misiak@gmail.com
}

\title{
TRADITIONAL NEIGHBORHOOD DESIGN AS A NEW URBANIST PRINCIPLE FOR THE REVIVAL OF POST-INDUSTRIAL CITY CENTERS: A COMPARATIVE STUDY OF LYON AND LODZ
}

Abstract: The purpose of this article is to evaluate the role of a Traditional Neighborhood Design (TND), one of New Urbanist principles, in the regeneration of post-industrial city centers. Its structure is the following. First, the contemporary elements of the TND are identified. Then, their actual versus declared use in strategies aimed at the renewal of major post-industrial sites is analyzed. Finally, the elements' ability to improve the spatial quality of an urban area is assessed. The above purpose is achieved by analyzing the application of the New Urbanist planning tools by two urban regeneration projects at different levels of completion. The sites of the projects are the central areas of the French metropolis of Lyon and of the Polish city of Lodz.

Keywords: New Urbanism, Traditional Neighborhood Design, regeneration of a post-industrial city center, Lodz, Lyon.

\section{WYWODZACCY SIĘ Z NOWEGO URBANIZMU TRADYCYJNY MODEL URBANIZACYJNY JAKO JEDNA Z ZASAD ODNOWY POPRZEMYSŁOWYCH CENTRÓW MIAST. STUDIUM PORÓWNAWCZE LYONU I ŁODZI}

Abstrakt: Celem autorów artykułu jest ocena roli tradycyjnego modelu urbanizacyjnego (eng. Traditional Neighborhood Design TND), jednej z zasad Nowego Urbanizmu, w regeneracji postindustrialnych centrów miast. Struktura artykułu jest następująca: w pierwszej części przedstawiono współczesne elementy wywodzące się z TND. Następnie przeanalizowano ich faktyczne i zadeklarowane wykorzystanie w strategiach odnowy obszarów poprzemysłowych. Na końcu oceniono ich efektywność - wpływ na poprawę jakości użytkowania przestrzeni. Powyższy cel został osiągnięty poprzez analizę zastosowania narzędzi planowania tradycyjnego modelu urbanizacyjnego (TND) w dwóch projektach rewitalizacji miast na różnych poziomach zaawansowania. Omawianymi przypadkami są obszary centralne metropolii Lyonu we Francji oraz Łodzi w Polsce.

Słowa kluczowe: Nowy Urbanizm, tradycyjny model urbanizacyjny, regeneracja centrów miast poprzemysłowych, Łódź, Lyon.

\section{INTRODUCTION}

The New Urbanism is promoted by its advocates it as an urban design strategy for creating a more human-friendly environment (Plaut, Boarnet, 2003). Because of its focus on open spaces and squares and roads functioning as the main outdoor rooms, the New Urbanism should be viewed as a movement in urban design emphasizing the benefits of reviving traditional neighborhoods (Piatkowski, Marshall, 2014) and offering a viable alternative to lowdensity, auto-dependent neighborhoods (Ellis, 2002) rather than an architectural style. According to Talen (2000), the centrepiece of the New Urbanism is the link between public space and a sense of community creating a spatial structure encouraging public interaction (Davis, Duany, and Plater-Zyberk, 1999; Leccese, McCormick, 2000).

In 1993 Andres Duany, Elizabeth Plater-Zyberk, Peter Calthorpe, Daniel Solomon, Douglas Kelbaugh and Scott Merrill, the prominent practitioners and theorists of New Urbanism, initiated the 
Congress for the New Urbanism (CNU) (Schuyler, 1997) at which the Charter of the New Urbanism (CNU, 2001) laying out its key principles was adopted. One of the most important of them is the concept of a traditional neighbourhood with a welldefined center, high-quality public spaces, a mixeduse area accessible within a 10-minute walk, and development density increasing to the center (Talen, 1999). The New Urbanism was originally created to mitigate the impacts of suburban sprawl, but today the range of its uses is much wider as the researchers have found it to be 'applicable at all scales, from high-density Manhattan neighborhoods to hamlets in the countryside' (Ellis, 2002, p. 267).

Set in the context of Bohl's assumptions about the application of the New Urbanism to inner-city (Bohl, 2000), this article evaluates the role of the Traditional Neighborhood Design (TND) as a New Urbanist principle used in the regeneration of postindustrial city centers where most revitalization projects are taking place today. In this way it provides an insightful comparison of theoretical findings and actual practices of modern cities.

The article is organized as follows. First, the contemporary elements of the New Urbanist Traditional Neighborhood Design are identified. Then, their actual versus declared use in strategies aimed at the regeneration of strategic post-industrial areas is analyzed. The aim of the analysis is to determine whether TND's elements can make an urban area more functional. Because of earlier evidence that 'Residents of the new urbanist neighbourhood [are] more likely to be physically active in their neighborhood than [are] residents of conventional suburbs' (Rodríguez, Khattak, and Evenson, 2007, p. 43), the authors of the article will seek to establish the correlation between TND elements and measures of land-use quality such as:

1. The size of the city center in relation to the entire urbanized area.

The knowledge of how the center of a city relates to the rest of its area or to other municipalities making up a conurbation is important for the effective management of complicated urban systems whose elements have to harmonize with their context (Hebbert, 2003). In studying the size ratios, areas covered by spatial policy also need to be considered because of Schuyler's thesis (1997, p. 353) "that New Urbanism developments must be linked to broad regional objectives, [...] expectations need to be tempered with reality [and] genuine change in the metropolitan landscape takes decades to implement".

\section{Population and development densities.}

Both measures show land-use intensity in the city center. According to the New Urbanist guidelines, the spatial structure of a traditional neighbourhood should be relatively dense and increasing towards its center (Marshall, 2003).

\section{Mixed-use functionality.}

According to New Urbanism pioneers, mixeduse is an important attribute of an urban area. A mixed-use area is characterized by the diversity, accessibility and proximity of buildings and public spaces (Schuyler, 1997) and by the appropriate composition of metropolitan functions in the city center. All these elements together show how liveable and attractive an area is (Farr, 2008). An analysis of mixed-use must also consider the locations of civic buildings because a true Civilitas (city) must consist of both res economica and res publica (Krier, 2009). The significance of civic buildings derives from the fact that they uphold the identity of a community and consequently its quality and sense of importance (Calthorpe, 1993).

\section{Public spaces.}

New Urbanists encourage street life because they believe that increased pedestrian interaction make places more secure and strengthens community bonds (Talen, 1997; Gallimore, Brown, and Werner, 2011; Piatkowski and Marshall 2014). The factor attracting people to some areas is a sense of place which can be quantified as a ratio between public (transit) spaces (squares, streets, greens, parks) and built-up spaces (Talen, 1997).

\section{Post-industrial and natural heritage.}

The post-industrial and natural heritage of cities consists of urban layouts, buildings and small architecture. All these assets define the identity of the city and of its residents. Calthorpe argues that equally important are parks and open spaces that bring together residents of community and provide the appropriate settings for civic structures just as churches, government buildings, and large residences do (Calthorpe, 1993). Because the spatial quality of an area largely depends on the physical condition and visibility of these components of local heritage, especially in the pedestrian-oriented systems such as New Urbanism (Katz, 1994; CNU, 2001), they too must be considered when the traditional neighborhood structure is examined. 


\section{METHODS OF RESEARCH}

The conducted research utilized a variety of both empirical and theoretical methods. Analyses focused on issues connected to urban pattern and spatial policy. The first part of the research used mainly the literature review, that allowed to single out key elements of TND. The second part of the research consists of empirical analysis of selected examples of problems defined in the first part. Both parts involved using analytical methodologies, critical approach towards sources of information, and referenced to quantitative and qualitative parameters. The analysis of morphological and organizational structure of researched cases involved use of planning documents (chapters: "The size of the city center in relation to the entire urbanized area" and "Post-industrial and natural heritage"). In the case study multiple partitive research methods, including spatial analyses and their statistical aspects. Among those mentioned earlier querying cartographic study, urban inventory and on-site research need to be distinguished. It was necessary to use statistical and demographical data from specialised institutions such as Urban Agency of the Lyon Metropolitan Area, Bank of Local Data and Head Office of Geodesy and Cartography in Lodz (chapters "The size of the city center in relation to the entire urbanized area" and "Population and development densities"). Additionally data from Urban Agency of the Lyon Metropolitan Area and the Municipal Urban Planning Office in Lodz were used, as well as public domain sources, for example Open Street Map, Copernicus Land Monitoring Service at the European Environment Agency - Urban Atlas. Collected data were processed and analysed using state of the art soft ware used for enabling spatial planning: Quantum GIS and AutoCAD Map 3D. Collected data allowed to complete a spatial (buildings density and structure, situation and distance between public spaces, function of areas) and morphological study (places of mixed- use functionality, public spaces) of both cities.

Direct observation of development of analysed cases served a complement to above analyses. The Authors of the research are inhabitants of Lodz and it allows them to be active observers and witnesses to changes happening in the city. Thanks to a research grant one of the Authors managed to conduct detailed on-site observations in Lyon.

Adopted template of research procedure enabled critical assessment of TND's impact. Use of com- parative case study allowed for elaboration of detailed conclusions of researched cases. The product of the research is a catalogue of recommendations that have practical reference to spatial transformation in Lodz and Lyon, as well as in spaces of similar profiles.

\section{DISCUSSION}

\subsection{THE SIZE OF THE CITY CENTER IN RELATION TO THE ENTIRE URBANIZED AREA}

Lyon and Lodz are the third most populous urban municipalities in France and Poland, but other than that they are very different from each other. Attributing the differences between them only to different administrative divisions of Poland and France would be a misleading oversimplification: the size relations in Lyon and Lodz give more credibility to the conclusion that they are rather due to different perspectives on spatial policy (Fig. 1).

Lyonis part of the vast Lyon metropolitan area (a topographically diverse region encompassing the Alps, Massif Central and Burgundy) where the intercommune cooperation is regulated by a set of principal directives called 'Inter-Scot'. 'Scot' (schema de cohérence territorial - a territorial coherence scheme) alone is an urban outline plan covering a smaller, yet significant area of the Lyon conurbation. The development of the basic unit of territorial collectivity called the Grand Lyon is governed by a single zoning plan (plan local d'urbanisme et de l'habitat - PLU-H) that aims to coordinate different urban functions and uses among communes.

This multi-level structure must lead to the question about where the center of Lyon is. According to the planning documents it consists of the communes of Lyon $\left(47.95 \mathrm{~km}^{2}\right.$ and 506,615 inhabitants) and Villeurbanne $\left(14.52 \mathrm{~km}^{2}\right.$ and 148,543 inhabitants). The two communes constitute $8.26 \%$ of the metropolitan Lyon area and $11.61 \%$ of the Grand Lyon area.

The documents do not show, however, the center of Lyon, which is widely deemed to consist of Presqu'île with the oldest part of the city Vieux Lyon $\left(1.93 \mathrm{~km}^{2}\right)$. The 'second city-center' is the central business district of Part-Dieu $\left(0.57 \mathrm{~km}^{2}\right)$ which has been undergoing changes since 1970s. Major revitalization processes can also be seen in Cité Internationale and Confluence $\left(1.66 \mathrm{~km}^{2}\right)$. 

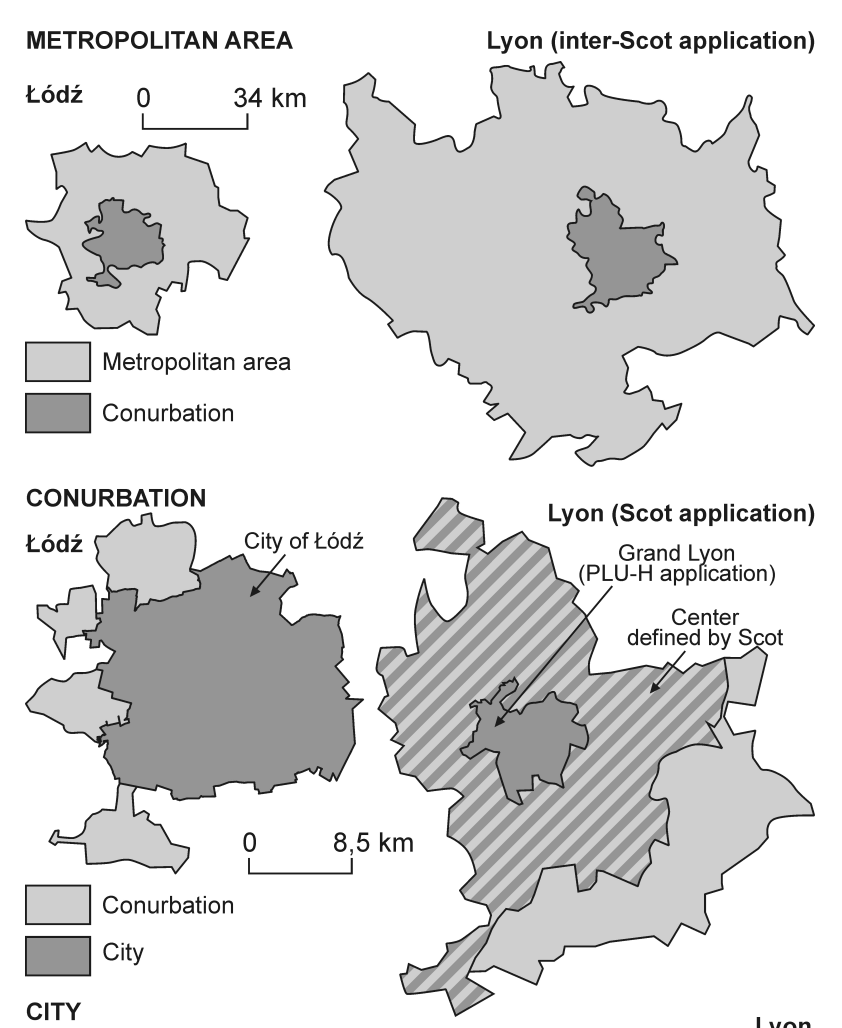

Figure 1. The central areas in Lodz and Lyon in relation to the entire urbanised area

Source: created from data available at the Urban Agency of the Lyon Metropolitan Area and the Municipal Urban Planning Office in Lodz and Open Street Map database

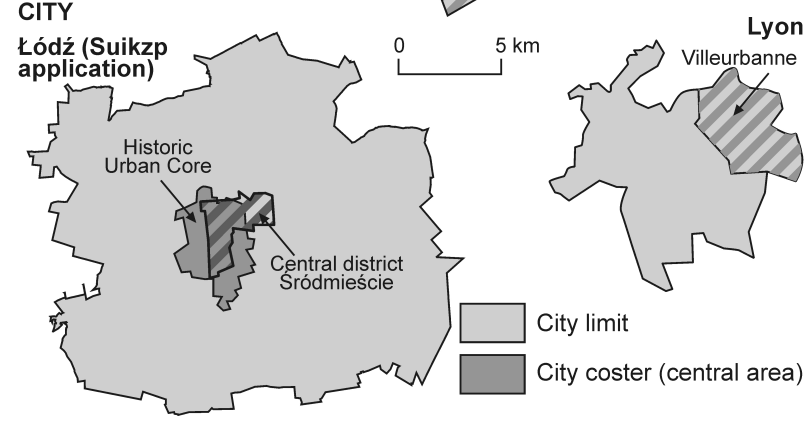

Figure 2. A comparison of development densities between Lodz and Lyon Source: created from data available at the Urban Agency of the Lyon Metropolitan Area, the Municipal Urban Planning Office in Lodz and Open Street Map database

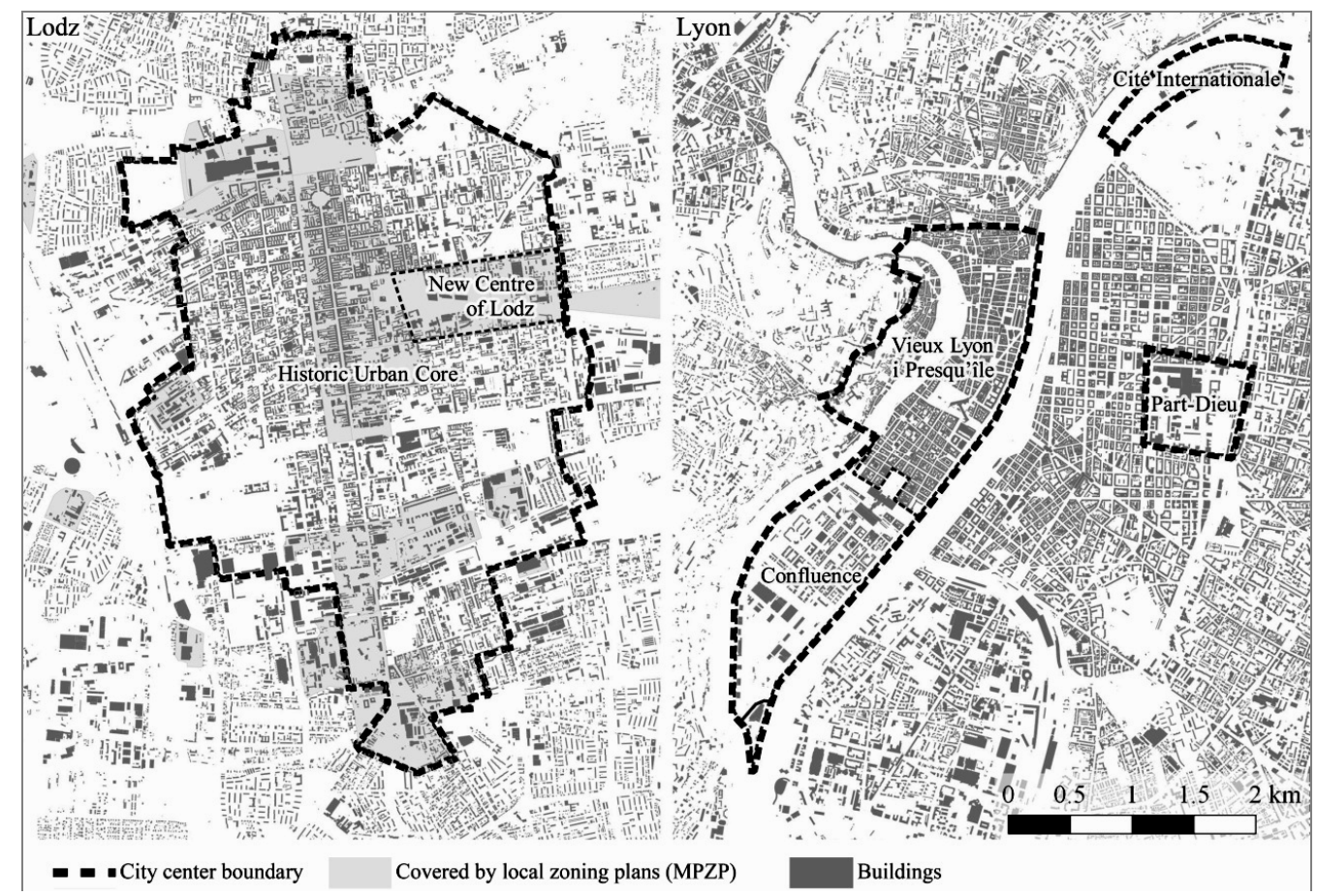


In this study, the center of Lyon is understood to encompass Presqu'île, Vieux Lyon, Part-Dieu, Cité Internationale and Confluence (Fig. 2) that together represent in area terms $8.67 \%$ of the city of Lyon, $0.55 \%$ of the Lyon conurbation, and $0.78 \%$ of metropolitan.

Although the planning documents of Lodz are more precise in defining its center, its interpretations vary depending on their purpose. From the administrative perspective, the center of Lodz (Śródmieście) covers $3.10 \%$ of the city's area and accounts for more than $22 \%$ of its population (Cysek-Pawlak, Krystkowski, 2018). For developer purposes, the term 'a central built area' is also used, denoting the part of the city where more lenient building permit requirements apply (allowing greater density of new developments, etc.).

The center of Lodz and its Historic Urban Core (HUC) are treated as equivalent notions in the city's planning documents. The same definitional approach has been adopted in this article. The Polish urban planning system is based on a fundamental document called the SUiKPZ (Polish title of the document: Studium uwarunkowań i kierunków zagospodarowania przestrzennego, in translation: a Study of conditions and directions of spatial development) that functionally resembles the French Scot but differs from it in scope (the Scot applies to the entire conurbation of Lyon while the SUiKPZis only prepared for the city of Lodz). The SUiKPZ calls the HUC the functional center of Lodz and the main stay of its image and identity. The modern shape of the HUC $\left(4.77 \%-13.95 \mathrm{~km}^{2}\right)$ of the city's area and around one-fifth of its population) was to a large extent determined by industrialization-driven urbanization processes in the $19^{\text {th }}$ and $20^{\text {th }} \mathrm{C}$ (Dzieciuchowicz, 2014).

A similar definition of the Lodz central area can be found in the city's development strategy, where the HUC is acknowledged as the oldest and bestshaped urban structure in the city with the largest number of grand residential buildings, impressive factories, and regular and full blocks of streets (UML, 2013). According to the Society of Polish Town Planners, the HUC is the largest of all urban structures present in the centers of Polish cities.

In March 2018, only 38\% of the HUC area was covered by local zoning plans (MPZP), a Polish equivalent of the French PLU-H prepared for Grand Lyon area. The rate is relatively low because following the collapse of communism in Poland the land use planning law was overhauled and all pre-1995 MPZPs were scrapped. As unsatisfactory as the rate is, it is still higher than the $19.6 \%$ rate noted for the whole city.

No strategic plans have been drawn up to ensure harmonious and coordinated development of the conurbation or metropolis of Lodz. The only documents available are broad in scope and express intentions concerning the development of the region.

\subsection{POPULATION AND DEVELOPMENT DENSITIES}

According to the data in Table 1, the center of Lyon is more than three times smaller than the center of Lodz. The administrative area of Lyon is six times smaller than that of Lodz but the metropolis and conurbation of Lyon are larger than their Lodz counterparts. Below, in order to find out how both cities implement the New Urbanist principle of traditional neighborhood, their areas, development density and population density rates indicating land-use quality are analyzed and compared.

The analysis of land-use quality in Lyon and Lodz is performed by comparing their downtown areas and entire urban areas (Fig. 3) in the framework of an urban planning model called Transect Planning created by the New Urbanists (Duany, Talen, 2002). The Transect Planning concept is consistent with the idea of a compact city (Neuman, 2005) and its purpose is to promote a built environment characterized by seamless connections between different density zones, from scarcely built-up rural areas through suburbs to densely developed centers.

Density transect occurs in both cities in question. In the metropolitan Lodz, population density rises steadily from 446 to 10,210 inhabitants $/ \mathrm{km}^{2}$ in the center. The respective numbers for Lyon are 271 and 12,687 inhabitants $/ \mathrm{km}^{2}$, meaning that metropolitan Lyon is less populated but has more inhabitants per square $\mathrm{km}$ in the center. If calculations were made without the river area, population density in central Lyon would go up to as many as 16,144 inhabitants $/ \mathrm{km}^{2}$, increasing the density ratio to 1.5:1 in its favour. As far as Lodz is concerned, the population density rate shows that its population has been decreasing since the late 1980s. According to the SUiKPZ, it was the HUC that lost more residents in the last two decades than other districts of the city. 
Table 1. A comparison of urban indicators between Lodz and Lyon

\begin{tabular}{|c|c|c|}
\hline Metropolitan area & Lyon & Lodz \\
\hline $\begin{array}{l}\text { Metropolitan area } \\
\text { Area } \\
\text { No. of residents } \\
\text { Population density (people per sq. km) } \\
\text { Development density }\end{array}$ & $\begin{array}{c}12,041 \mathrm{~km}^{2} \\
3,256,531 \\
271 / \mathrm{km}^{2} \\
1.47 \% \\
\end{array}$ & $\begin{array}{c}2,499 \mathrm{~km}^{2} \\
1,086,993 \\
446 / \mathrm{km}^{2} \\
1.23 \% \\
\end{array}$ \\
\hline $\begin{array}{l}\text { Conurbation } \\
\text { Area } \\
\text { No. of residents } \\
\text { Population density (people per sq. km) } \\
\text { Development density }\end{array}$ & $\begin{array}{c}753 \mathrm{~km}^{2} \\
1,419,397 \\
1,886 / \mathrm{km}^{2} \\
7.16 \%\end{array}$ & $\begin{array}{c}410 \mathrm{~km}^{2} \\
869,682 \\
2,123 / \mathrm{km}^{2} \\
5.04 \%\end{array}$ \\
\hline $\begin{array}{l}\text { Grand Lyon (Métropole de Lyon) } \\
\text { Area } \\
\text { No. of residents } \\
\text { Population density (people per sq. km) } \\
\text { Development density }\end{array}$ & $\begin{array}{c}534 \mathrm{~km}^{2} \\
1,350,000 \\
2,538 / \mathrm{km}^{2} \\
9.62 \%\end{array}$ & $\mathrm{n} / \mathrm{a}$ \\
\hline $\begin{array}{l}\text { City } \\
\text { Area } \\
\text { No. of residents } \\
\text { Population density (people per sq. km) } \\
\text { Development density }\end{array}$ & $\begin{array}{c}47.95 \mathrm{~km}^{2} \\
506,615 \\
10,538 / \mathrm{km}^{2} \\
23.96 \%\end{array}$ & $\begin{array}{c}293.25 \mathrm{~km}^{2} \\
693,797 \\
2,366 / \mathrm{km}^{2} \\
7.47 \%\end{array}$ \\
\hline $\begin{array}{l}\text { Center } \\
\text { Area } \\
\text { No. of residents } \\
\text { Population density (people per sq. km) } \\
\text { Development density }\end{array}$ & $\begin{array}{c}4.29 \mathrm{~km}^{2} \\
59,248 \\
12,687 / \mathrm{km}^{2} \\
35.4 \%\end{array}$ & $\begin{array}{c}13.95 \mathrm{~km}^{2} \\
142,432 \\
10,210 / \mathrm{km}^{2} \\
27.2 \%\end{array}$ \\
\hline
\end{tabular}

Source: created by the authors based on 2017 data from the Urban Agency of the Lyon Metropolitan Area, 2013 data from the Bank of Local Data and the Head Office for Geodesy and Cartography in Lodz (no. of residents living in the center of Lodz), 2015 data (the Lodz metropolis) and 2017 (other data).

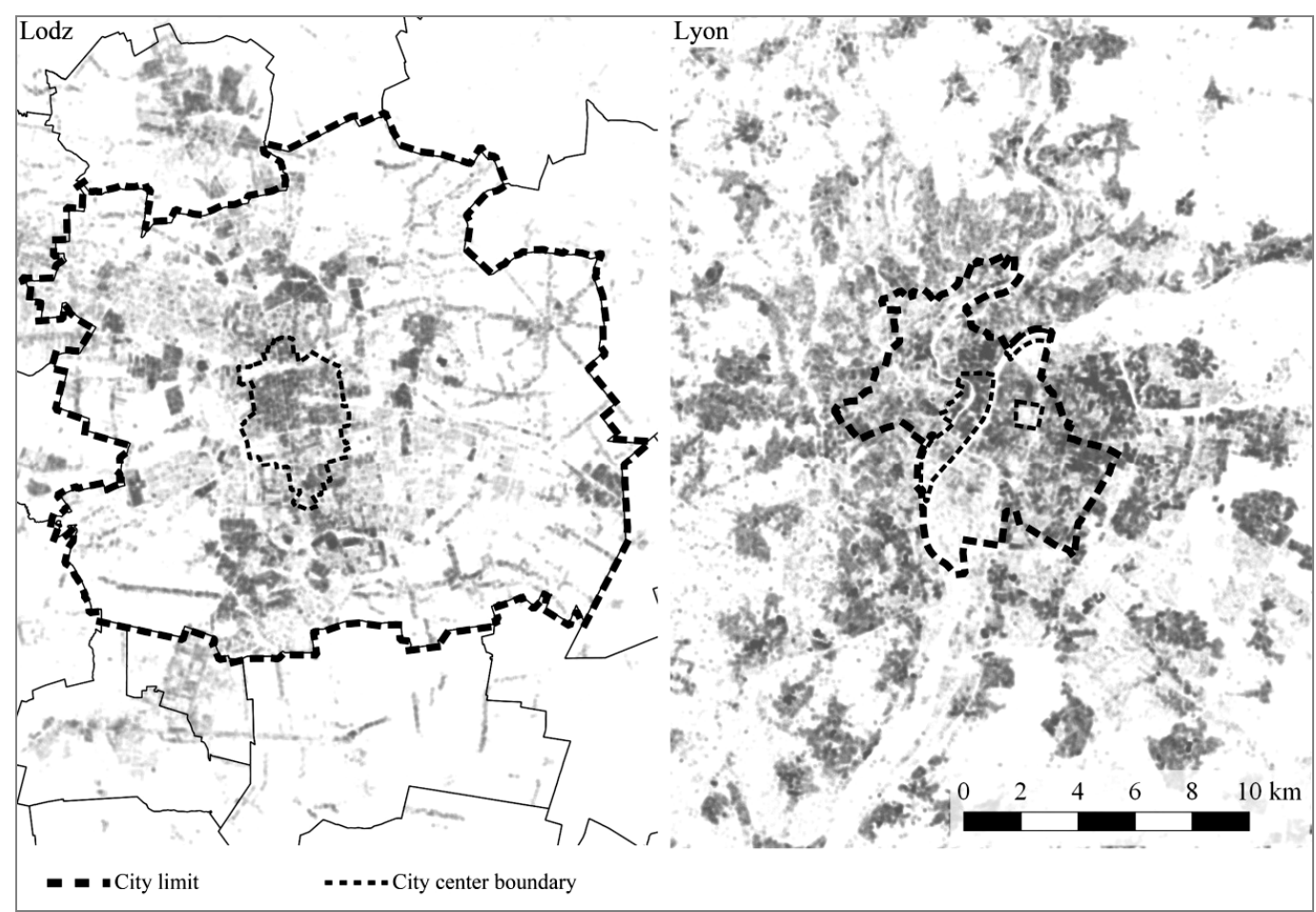

Figure 3. A comparison of development densities between Lodz and Lyon

Source: created from data available at the Urban Agency of the Lyon Metropolitan Area, the Municipal Urban Planning Office in Lodz and Open Street Map database 
The intensity of depopulation processes and population density vary across the center of Lodz. Inside its relatively large area there are densely populated 'local centers' as well as places with few inhabitants. This irregular distribution of population is probably due to many downtown sites having fallen into a state of neglect and disrepair (almost all of the HUC area is covered by the revitalization plans) (Kaniewicz, Nowakowska, Wosiak, 2002; Dzieciuchowicz, 2009a,b, 1984). In the center of Lyon, population density variations are caused by the diversity of buildings. The highest population densities are noted in Part-Dieu and then in Cité Internationale. The population density in the center is, however, not as high as the two districts might suggest because its overall level is reduced by the less populated historic districts of Vieux Lyon, Presqu'île and post-industrial Confluence.

As important in evaluating land-use quality as population density is the density of development. In this study, it is calculated as a ratio of developed land to total urbanized area. As could be expected, its values follow the same trend as population densities: in both cities they increase towards the center and vary considerably within its borders.

The Lodz rate of development density, $7.4 \%$, is worryingly low. In the city center it is significantly higher, $27.2 \%$, but still does not compare with Lyon's 35.4 or $40.17 \%$ (the latter value omits the river area). The highest development density is noted in the HUC where major investments and new development projects are needed to make up for the different quality of its parcels ad their unequal access to public spaces (Wiśniewska, 2009; Wiśniewski, 1984; Koter, 2009).

In the center of Lyon, the cause of variations in development densities is different types of buildings in its area. The highest development density occurs in the complete historic systems of Presqu' île and Vieux Lyon, followed by Part-Dieu, Cité Internationale and Confluence. Research has shown that Confluence owes its present urbanscape primarily to the fact that a large part of the revitalized area has been given over to pedestrians and recreation, and to improvement processes aimed at increasing the density of development, etc., that are yet to be complete (Kazimierczak, 2014).

\subsection{MIXED-USE}

Because the New Urbanism emerged as a reaction to single-function neighborhoods, its emphasis on mixed-use (Schuyler, 1997) and the age, income and education diversity of users seems quite natural (Amin, Thrift, 2002; Trudeau, Kaplan, 2015; Foster, Hooper, Knuiman, Bull, Giles-Corti, 2016). There is, however, no consensus among urban planners on whether there is a fixed set of diverse land uses and users that would be right for the centers of all cities. Reaching it will not be easy because of incomplete datasets providing spatial reference information on some cities, such as Lyon. This incompleteness also caused that the authors could not analyze Lyon as thoroughly as Lodz.

In analyzing a city center with respect to the mix of functions the first step should be to examine whether the mix is more prestigious than in the suburbs. To this end, the structure of the metropolitan functions has to be investigated, for instance to determine whether a downtown area has more residential functions than public ones. According to the Urban Atlas, metropolitan functions occur not only in the city centers but also in Central Business Districts provided that they also include residential areas. The centers of Lodz and Lyon have very similar shares of metropolitan functions, respectively $62 \%$ and $59 \%$ (Fig. 4), which are supplemented by functions addressing the needs of the public, such as commercial, industrial, sports and leisure facilities (Fig. 5). The historic part of the center of Lyon (Presqu'île and Vieux Lyon) has significantly more public institutions compared with its newer areas. In the center of Lodz, a concentration of public institutions can be seen on Piotrkowska St., which is the main street in the city and the compositional axis of its Historic Urban Core (Wolaniuk, 2002a, b).

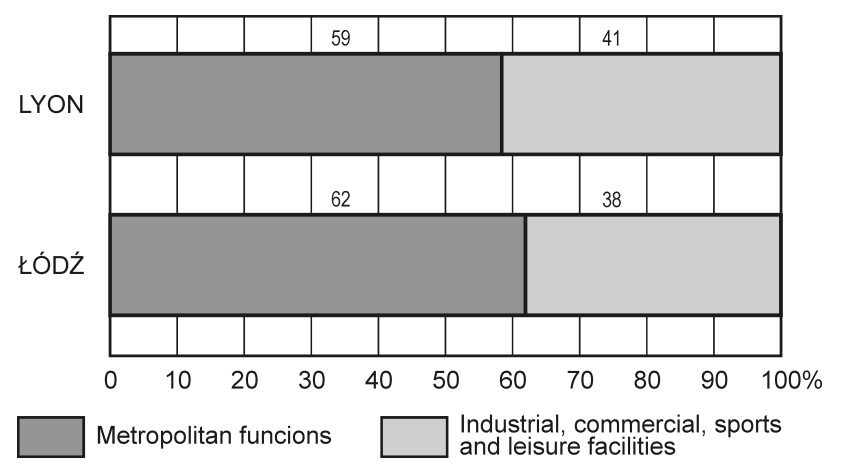

Figure 4. Principal urban functions in the center of Lyon and Lodz

Source: developed by the authors based on the Urban Atlas and field research data

The center of Lodz has relatively equal proportions of residential and service functions, ranging from $41 \%$ to $44 \%$. Its major metropolitan functions 


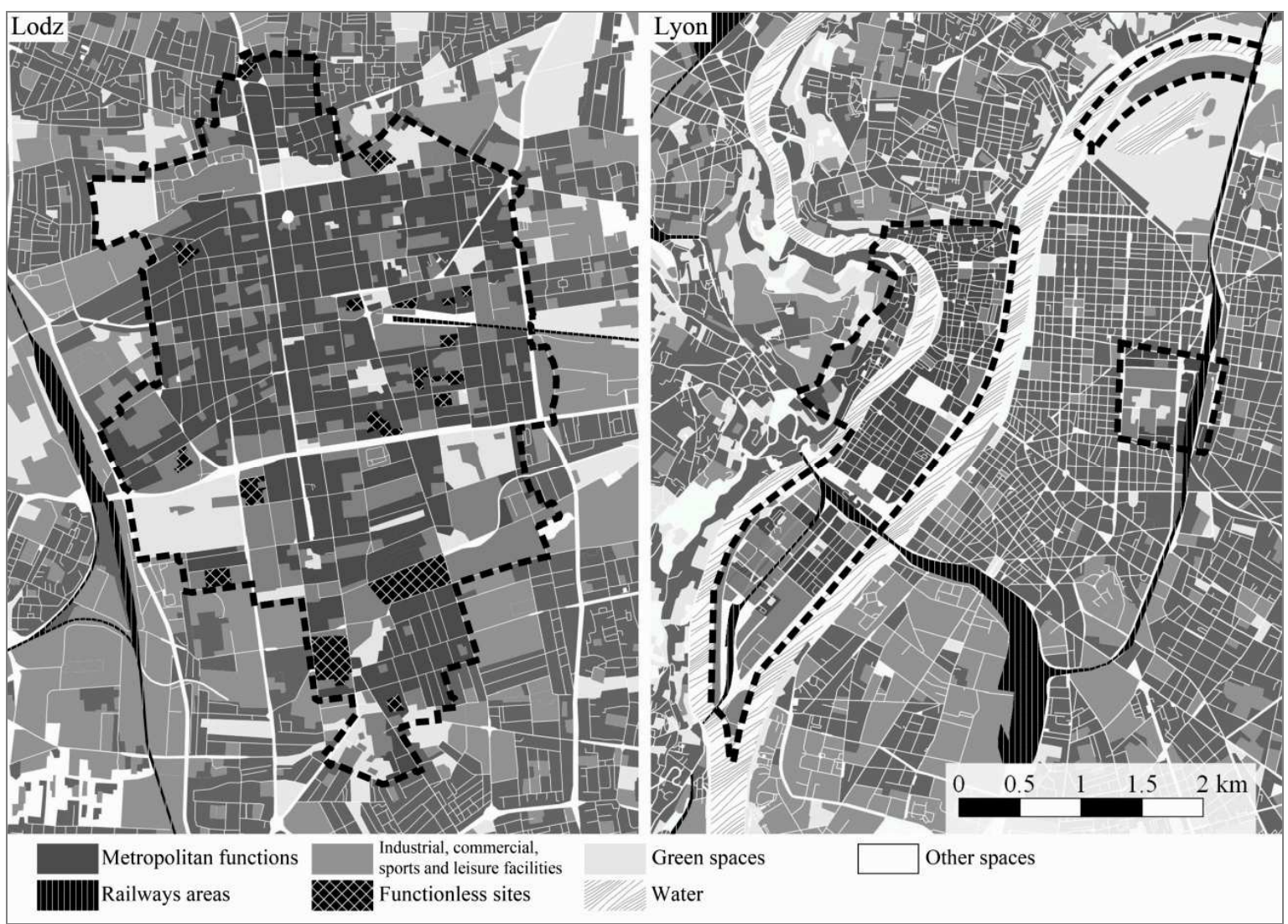

Figure 5. A comparison of the distribution of principal urban functions between Lodz and Lyon Source: created based on data sourced from the Urban Agency of the Lyon Metropolitan Area, the Municipal Urban Planning Office in Lodz and the Open Street Map database

contrast with a large area occupied by active manufacturing enterprises, which accounts for $15 \%$ of developed land (exclusive of vacant and abandoned parcels). In Lyon, most of its central area is used by retail establishments. Its historic and more recent parts together account for $60 \%$ of commercial activity in the conurbation and for $40 \%$ of non-food trade.

In order to learn more about the composition of urban functions in Lodz, the types of developments in the city need to be analyzed. Because much of the city's area has retained its historic tenement buildings and old factories (SUiKPZ, 2018) and in fills from later times are relatively few, the HUC is the landmark of Lodz identity and past. Housing developments in its area consist of tenement buildings (77\%), blocks of flats $(22 \%)$ and new multi-family and single family buildings (only 1\%). As in Lyon, the service (commercial) space is mainly used by retailers such as large-format stores and service providers $(79 \%)$. The other $21 \%$ is occupied by public buildings (administration, offices, healthcare and tertiary education complexes).
Interesting observations can be made by juxtaposing the above data with what is proposed by contemporary projects addressing the needs of downtown areas, such as the New Center of Lodz (NCL) and Confluence in Lyon. The French case is emblematic of efforts aimed to remove industry from the city center. The old industrial area of Confluence is now mostly used for service establishments (64\%) and housing developments (36\%). The most recent MPZP document (including information on projects that have been or are to be completed) shows that in the NCL service establishments will account for as much as $75 \%$ of its developed area. This and the nature of the approved projects imply that the NCL will primarily function as an office district. The other $25 \%$ of its area are intended for housing developments and quasi-hotels and other facilities providing temporary accommodation services.

\subsection{PUBLIC SPACES}

A stepwise analysis based on the available source data was also used to investigate public spaces in the centers of Lyon and Lodz. First, the ratios 
between public spaces and developed areas (blocks) and the shares of public space components (i.e. roads, squares, greens, etc.) will be presented. Then they will be looked at from the perspective of specific, smaller-scale strategic projects to see urban policy in working. Lastly, a qualitative analysis of public spaces will be performed and its findings will be used in the final evaluation of the use of the TND concept in the revival of post-industrial city centers.

Public spaces are widely viewed to consist of squares, streets, parks and greens that for centuries have been used by the townspeople to meet, trade, exchange information and entertain themselves. As well as shaping and defining the urban structure, public spaces, most of which are enclosed by buildings, also serve as orientation points that make it easier for people to navigate around the city or town (Rykwert, 2013). Krier (2009), one of the New Urbanism pioneers, estimated that public spaces should account for ca. $25 \%-35 \%$ of the district's area. In the center of Lyon the rate is slightly higher $(39.5 \%)$. The reason for this is not the city's council lavish approach to urban planning, but the metropolitan character of downtown Lyon and a considerable share of dense historic grids of streets, squares and green spaces. The Lodz rate of $26.1 \%$ fits within the range proposed by Krier. The urban fabric of Lodz has also emerged from historical processes, but its development was subordinated to the special needs of small manufacturing shops and manufacturing industry. As a result, Lodz has relatively large blocks of streets (270 by $290 \mathrm{~m}$ on average) consisting of disproportionately long and narrow parcels $(20$ by $300 \mathrm{~m}$ ) that in the past were divided between the shop and a field where cotton and flax were grown (Koter, 2009; Wiśniewski, 2009; Dzieciuchowicz, 2011). In other European cities blocks of streets are much smaller, for instance $60 \times 70 \mathrm{~m}$ in Lyon, $90 \times 100 \mathrm{~m}$ in Lille, and $120 \times 120 \mathrm{~m}$ in Barcelona.

Large blocks of streets resulted in Lodz having a comparatively lower street grid density. In the wake of the modernist concept of east-west and north-south thoroughfares cutting through the center of the city that was adopted in the post-war years to guide the construction of new roads, the historic fabric of the city was damaged by the demolition of many buildings. A number of the boldly planned corridors have never been used, leaving gaps that disturb the proportions of public spaces and depriving the streets of their traditional function of places that people use not only to get from one point to another but also where they spend time (Orlowski,
1984; Wiśniewski, 1984). The majority of public spaces in downtown Lodz are represented by streets and roads (47.9\%) and parks (45.2\%) (Fig. 6). Occupying merely $1.2 \%$ of the central area (where the functionless sites account for $4.5 \%$ ), squares are practically insignificant as an element of public space. The shortage of squares must be worrying especially in the context of Alexander's view (1987) that squares should be the largest and most public "rooms in the city" and that the distance between them should not exceed several hundred meters if they are to function as true centers of local community life. The criterion is met by Lyon where the squares in the historic part of Lyon are on average $250 \mathrm{~m}$ from each other (in straight line), but not by Lodz $(1 \mathrm{~km})$ (Fig. 7).

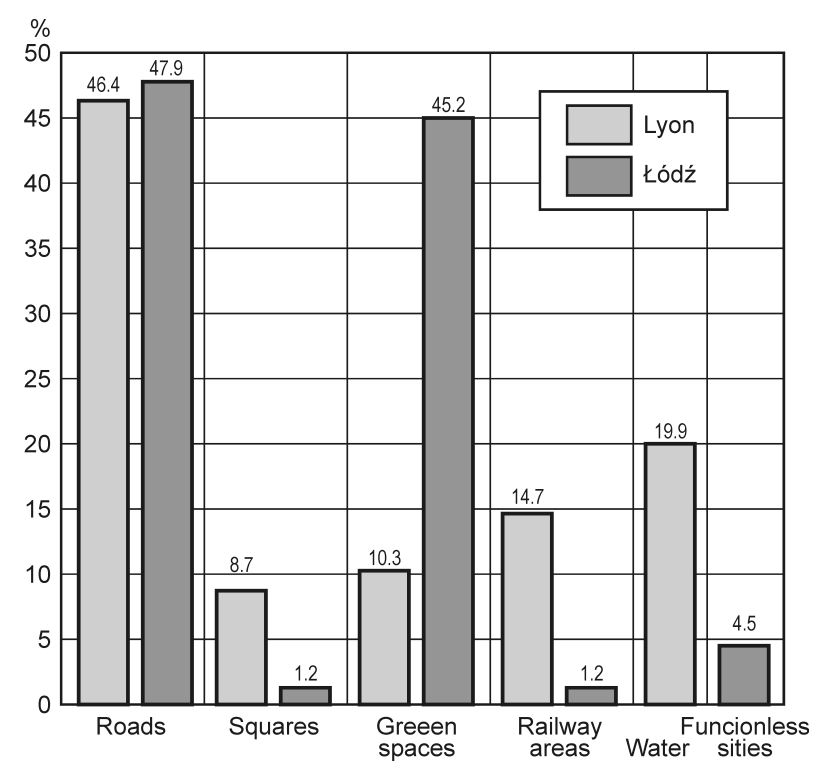

Figure 6. Public spaces in downtown of Lyon and Lodz Source: developed by the authors based on the Urban Atlas and field research data

The tendencies arising from projects carried out in Lodz are also worrying. In the NCL which is the largest and, presumably, the key project undertaken by the city public space is used for a road system occupying $1 / 3$ of the NCL area and squares are exceedingly large. The square before the multimodal railway station (the main public building in the NCL) is almost $100 \mathrm{~m}$ long and $200 \mathrm{~m}$ wide, which is at odds with the New Urbanist rule that requires a square not to be wider than $21 \mathrm{~m}$ while imposing no restrictions on its length (Alexander et al., 1977, p. 318).

The old section of the center of Lyon (Presqu'île and Vieux Lyon) has definitely more squares and non-motor roads compared with Lodz. The more 


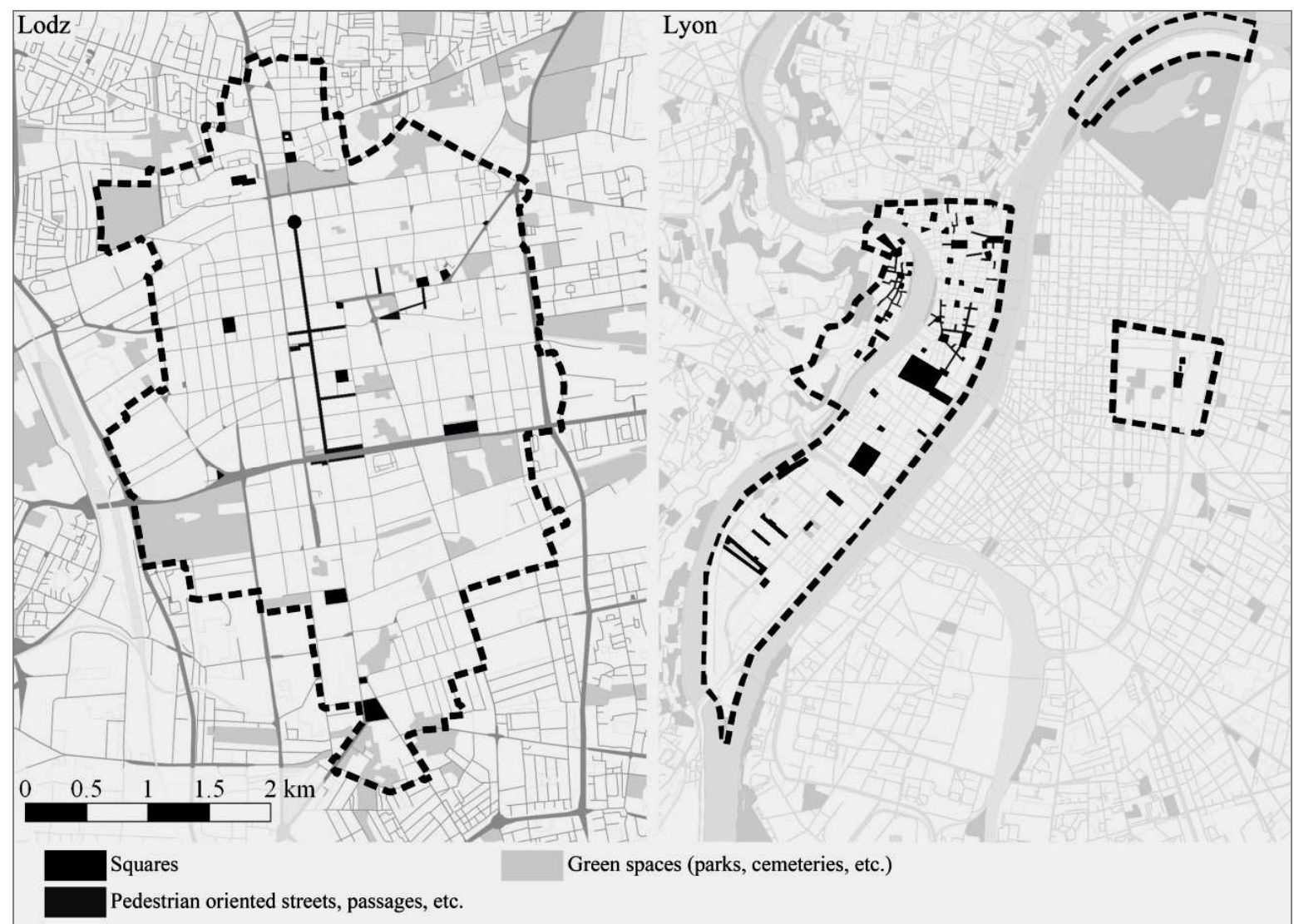

Figure 7. Distances between squares in Lodz and Lyon Source: created from data available at the Urban Agency of the Lyon Metropolitan Area, the Municipal Urban Planning Office in Lodz and the Open Street Map database

modern districts of Part-Dieu, Cité Internationale and Confluence are very different from it. In Confluence open green spaces and water account more than half of its area (Kazimierczak, 2014), with a relatively insignificant share of "traditional", welldefined interior spaces such as squares.

The shares of different types of public spaces in the center of Lyon are relatively proportional: squares constitute $8.5 \%$, green areas $10.3 \%$, railways areas $14.7 \%$, and water $19.9 \%$. The high rate of railway areas is due to the high-speed railway line running through the city center and the main station building that was constructed over ground unlike its Lodz counterpart that is largely hidden below the ground level. Like in Lodz, public spaces in the center of Lyon are dominated by roads that account for almost half of its area $(46.4 \%)$. The infrastructure policy that both Lyon and Lodz pursued in 1970s gave priority to individual motor transport in the city centers. The fast transit roads that were constructed to enable it reduced the historic area of the city by $1.5 \%$ space and affected the composition of the center of Lyon.
According to Lynch (1960), legibility understood as the ease with which city sections can be recognized and put into a coherent system is a key value in organizing the city. The system should have a sub-system of high-quality public spaces, i.e. of appropriately hierarchized, easily accessible, safe and interconnected places. Well-designed squares and streets encourage pedestrians to use them and provide a platform for social contacts in the community, thus increasing the integration of local residents and making them feel safer (CNU, 2001). Given their ability to strengthen local identity, the main primary public buildings and squares should be given central locations in the city, etc., and their design should correspond to their status and distinguish them from the surrounding urban fabric (CNU, 2001). Research has shown that high-quality urban spaces have a positive effect on residents' physical and mental health, foster the healthy development of children, facilitate social contacts and reduce crime rates, as well as increasing property prices and the volume of local business (e.g. retail trade). Well-defined streets and squares that discourage drivers while attracting pedestrians and 
cyclists stimulate local communities to greater activity (CABE Space, 2004).

The quality of public spaces in Lodz is an important factor in the evaluation of its attractiveness. A 2011 survey commissioned by the MPU (Lodz Municipal Urban Planning Office) showed that of all streets in Lodz only Piotrkowska was expressly associated by respondents with a public space. Other popular spaces in the city were greens, mainly parks and pedestrian alleys. The quality and tidiness of public spaces were rated low, mainly because of the insufficient numbers of litter baskets, benches, cycle racks and public toilets (MPU, 2018; Tobiasz-Lis, 2008).

In the HUC area there are 15 squares, some of which are not used as originally intended but as parking lots, public transport hubs or market places. Moreover, as 5 squares do not have distinct and clear boundaries, their spaces are difficult to define. The "blurred boundaries" problem is common across the HUC.

A special cause of the negative perception of downtown Lodz is void street corners in many prominent sites, blind side walls of tenement buildings (many of which are in bad need of repair), voids in facades, and courtyards that can be watched from the street. The accumulation of these defects is worrying, because the quality of urban spaces is important in evaluating the attractiveness of the city (its competitive advantage), likewise its ability to use the distinctive local assets, including cultural, historic and natural assets, or the uniqueness of place (ECTP-CEU, 2003).

The quality of public spaces in Lyon appears to be is better than in Lodz, especially in the areas north of the Perrache railway station (in the central part of the peninsula), where most blocks of streets have well-defined edges, different types of spaces are distinctly separated from each other, and squares and streets have recognizable interiors. A somewhat lower quality of public spaces occurs in Part Dieu, Confluence and near the Perrache railway station where the density of development is much lower. Confluence, which was planned on the late modernist principles, is the least densely developed of the three districts, with some buildings standing alone amid green areas, roads and parking lots. Although Confluence still has the problem of postindustrial voids, new developments and the efforts to transform public spaces based on local historic and natural assets are very promising. It is very likely that in the future this part of Lyon will become attractive as its historic districts.

\subsection{POST-INDUSTRIAL AND NATURAL HERITAGE}

The identity of Lodz and its residents is defined by the city's post-industrial heritage dating back to the $1^{\text {th }} \mathrm{c}$., which consists of several thousands of grand tenement buildings, several tens of residences and villas built for factory owners, several hundreds of post-industrial complexes, parks, as well as gardens, squares and greens (UML, 2013). Together with the chessboard of mostly perpendicular streets they make up the distinctive metropolitan fabric of the Historic Urban Core. In some places the fabric is irregular: high tenement buildings contrast with low-rise buildings, residential properties with old factory buildings, palaces and villas with outbuildings or dilapidated structures, and densely developed sites with void parcels. There is a distinct lack of hierarchy, or at least of a legible system, of public spaces. There are few characteristic vista axes or terminations of street vistas. Many public spaces, including the city squares, are only partly enclosed by buildings as a result of hard-dying planning mistakes some of which were made back in the 1820 s, in the early years of modern Lodz. The $19^{\text {th }} \mathrm{c}$. layout of Lodz, which then consisted mainly of manufacturing settlements, was special and unique across Europe, but also heavily focused on the technological needs of local industry (Ostrowski, 1996; Koter, 1969). The beauty of urban composition and the needs and wants of a big city that Lodz was turning into were secondary. Lodz expanded at a fast rate, sometimes chaotically, in an uncontrolled manner. From a small farming settlement that in the early 19th $\mathrm{c}$. had fewer than 700 inhabitants the city developed within 120 years into a powerful industrial center with a population of almost 700,000 before the World War II (Suliborski, Dmochowska, Dudek, 2014; Wójcik, Tobiasz, Lis, 2014).

With all the weaknesses of its original layout (not unusual for a 19th $\mathrm{c}$. metropolises), Lodz was special in many respects. With its cityscape being increasingly appreciated, a large area of Lodz (encompassing Piotrkowska St. with the finest tenement buildings and contiguous areas, the most precious parts of post-industrial sites, the Old Cemetery and the New Jewish Cemetery) was listed several years ago as a Monument of History called "Lodz - a multicultural landscape of an industrial city". This special status is granted by the President of Poland to protect immobile heritage of special historic, scientific and artistic value. 
As the urban structure of Lyon embodies more than 2000 years of the city's history, its $19^{\text {th }}$ c. postindustrial heritage is but a fraction of its rich material past. The built environment in Lyon consists of buildings representing most historical epochs, from Roman times through Middle Ages, Renaissance, Baroque, Classicism and industrial revolution, up to present times. Because urban planners in Lyon have always had to adjust their ideas to the topographical conditions, Lyon has a less regular grid of streets compared with Lodz, with the shapes and routes of some streets having been planned to harmonize with the relief of the land. Because the compact grid of Lyon's medieval streets was appreciated through centuries, it was carefully preserved even in the $19^{\text {th }} \mathrm{c}$. When new roads were planned as part of the effort to reorganize the city and make it friendlier to its inhabitants. The concurrent industrial expansion in Lyon's peripheral areas such as Perrache (Confluence) did not affect its historical center either. The industrial character of Confluence was corroborated with the construction of a railroad line with viaducts and the Perrache railway station, which cut the central peninsula of the city into two parts and consequently marginalized the significance of Confluence as a residential, commercial and entertainment area. Although textile factories were located in other parts of the city, Confluence played a big role in the development of Lyon as a major transportation hub with an inland port, a railway line, a coal unloading facility and range of manufacturing establishments. After World War II, the first in Lyon HMB housing estate with council and cooperative units meant for railway personnel was built in the eastern part of Confluence (Kazimierczak, 2014).

Lyon is special in its ability to adapt its urban fabric to the requirements and needs of new epochs. Its historic fabric has been shaped by developments commissioned by wealthy local merchants and artisans. New public buildings were carefully designed to harmonize with high-quality tenement buildings decorated on the front and yard walls.

Because of the diverse and rich history of Lyon and the multitude and quality of its historic buildings (174 have the status of historic monuments), but most of all due to the strong identification of its residents with their city and their resolution to preserve and protect its values the historic part of Lyon has been entered in the UNESCO World Heritage List (Unesco, 1998).

Lodz is set among gently rolling hills that in the densely developed center of the city are hardly noticeable. After intense industrialization consumed local forests and most small rivers and streams were directed into cement channels and underground, the natural assets of the area that had led to the establishment of a manufacturing settlement by the first settlers were erased from the city's landscape.

In the HUC area, green spaces, mainly planned greenery (8.6\%) including 10 parks ( 9 of which are listed as historic monuments), squares and alleys account for $9.3 \%$. The rate is theoretically high, but the distribution of green spaces in the HUC is so uneven that most blocks either do not have it at all or the rate is less than 1\% (MPU, 2018). The natural green spaces are typically found on undeveloped parcels or in areas redeveloped due to residential or road construction projects. Although many of them can be seen in the central parts of Lodz their quality is poor.

Many streets in the center of Lyon have no trees so it appears to be less green than downtown Lodz, but the existing green spaces seem to be better organized. Most of them can be found in the most prominent public spaces, such as squares, some streets and the river boulevards, as well as around the Cité Internationale and on the Fourvičre hill adjacent to the city center.

An important natural component of Lyon's landscape is water. The Rhone and Saône rivers that through history determined the city's expansion are today integrated into revitalization projects. In Confluence, for instance, a trading and leisure complex and a housing estate have been developed around an artificial marina connected with the Saône. New, architecturally interesting buildings are developed along the river or old buildings are adapted to new uses, e.g. La Sucričre, an old warehouse that has been turned into an arts exhibition center.

The revival of Confluence has been going on for several years now. This once-industrial district is now a place with attractive housing estates, service facilities and high-quality public spaces, such as the Place des Archives near the Lyon-Perrache station, a former prison building that is now used by the Université Catholique de Lyon, or the indoor flower market adapted to a sports center. With all these changes, the post-industrial legacy of Confluence can still be seen in many public spaces: in the old docks area the railway tracks, the paving and the cranes have been retained. Like in Lodz, many projects in Confluence are designed so that they match the context of place and enhance the existing urban fabric. 
The revitalization efforts in Lodz have long concentrated on giving new uses to post-industrial buildings. Some of them have been turned into offices or housing units and others have become prominent cultural centers with museums, art exhibitions, concert halls, or various (also niche) art studios. Some of the old manufacturing complexes house today a variety of functions. The most spectacular of those is the Manufaktura, a 19th $\mathrm{c}$. cotton factory built for Israel Poznański. Its buildings now house the branch of the art museum of Lodz, a hotel, a cinema, various restaurants and entertainment facilities, and, last but not least, a shopping mall. The heart of the Manufaktura is a "marketplace" that has become one of the most important public spaces in the city (Janiszewska, Klima, Rochmińska, 2011; Piątek, 2006; Wójcik, 2010; 2009; Mordwa, 1993). Another interesting example is the Franciszek Ramisch factory on Piotrkowska St. Rather than turning it into a typical commercial space and "grooming" its originally rough walls, part of it was allocated to creative and independent projects, such as artists' studios, offbeat restaurants, etc. Over the course of several years, the constantly evolving and changing site of Off Piotrkowska has become one of the favourite places among locals and visitors alike.

There are two main lessons that can be drawn from the above analysis. Firstly, the right use of historic heritage places can make a city more attractive for both residents and visitors. Secondly, new, carefully selected uses of historic buildings and complexes can make them residents' favourite places to spend their free time in the city.

\section{CONCLUSION}

The study was undertaken to compare the attributes of a traditional neighbourhood design with actual projects aimed to regenerate post-industrial city centers. Unlike earlier analyses (Trudeau, 2013), this one focuses on the key determinants of this process, namely (1) the size proportion between the city center and the entire urbanized area, (2) population and development densities, (3) mixed-use of land, (4) public spaces (5) post-industrial and natural heritage of the city.

The research has showed where the Lodz and Lyon projects should be changed or improved with respect to the five factors. Lodz appears to have a special problem with the size proportion between its center and the entire urbanized area. While it is 6 times larger than Lyon, in some parts of it urbanization rates are low. The urbanized area $\left(143.7 \mathrm{~km}^{2}\right)$ constitutes $49 \%$ of the total area of the city. In Lyon, the area of the city matches the urbanized area. Because of the authorities' multi-level spatial policy, the metropolis develops relatively evenly towards its nucleus. This approach is consistent with the concept of a neighborhood as a basic unit of planning characterized by limited physical size, welldefined edges and a focused center (Fainstein, 2000). The HUC in Lodz is too large to meet all criteria of a compact and coherent neighborhood that according to Ch. Aleksander (1977) should be relatively small so that its users, mainly local residents, can readily identify it. The Polish Society of Town Planners has described the HUC as a place where the city holds many high-profile events but also as a place of contrasts with vacant buildings and functionless and derelict sites. The downtown Lyon has similar problems, but research shows that their impacts are not so obvious.

According to the walking city and transit city concepts (Newman, 1996), population density should range, in the first case, from 10,000 to 20,000 residents per $\mathrm{km}^{2}$ in the city center and in the second case from 5,000 to 10,000 residents per $\mathrm{km}^{2}$ in areas where development density increases towards the center. The first criterion was fulfilled by the centers of both Lyon (12,687 residents per $\mathrm{km}^{2}$ ) and Lodz (however, with 10,210 residents per $\mathrm{km}^{2}$ Lodz was only slightly above the recommended lower limit). The second criterion was not fulfilled by Lodz as a whole, as a result of low landuse densities in many areas inside its administrative borders. In Lyon, the development density is higher and clearly rises towards its center, and the city itself is much more compact.

In both Lyon and Lodz urban policies took account of mixed-use, an urban planning principle promoted by the New Urbanists. The proportion of post-industrial spaces in the center of Lodz is still significant, but their area diminishes as new, more prestigious functions are introduced. The approach, as well as the Confluence efforts to introduce new uses in its area, is aimed to improve the public image of the city center by providing it with a wider and more diverse range of local functions. It is also consistent with the walkable neighbourhood principle (Alidoust, Bosman, Holden, 2018) that like other principles underpinning a traditional neighborhood design promoted by New Urbanists is aimed to enhance the sense of security (Foster, Hopper, 
Knuiman, Bull, Giles-Corti, 2016). One of the factors determining the sense of security is the ratio between spaces allocated to motor traffic and to other functions.

In this study, the ratio was analyzed as part of the quality evaluation of public spaces in the centers of Lyon and Lodz. In both of them, as the analysis showed, the quality of their neighborhoods could be improved by imposing traffic restrictions. Researchers studying New Urbanist principles concluded that the reduction of motor traffic volume is required for a neighborhood to have a distinct, unique identity (Appleyard, Lintell, 1971). The recommendation is supported today by detailed calculations showing the impact of motor traffic on land-use quality. The connection between the two factors can be easily found even in a study as basic as this one.

Lyon has a system of high-quality public spaces consisting of the well-defined and harmonized interiors of streets, squares and boulevards. The grid of Lodz streets is clear-cut and legible, but the overall impression of the city is somewhat disappointing because of many voids in the urban fabric that impair the legibility of street and square spaces.

In both Lyon and Lodz the main factor determining the unique character of the cities and their identity is post-industrial heritage. In order to highlight its presence, old factory buildings and warehouses are adapted to new uses functions such as exhibition halls, offices, shops or restaurants. However, in neither of the cities have revitalization efforts blurred the line between their post-industrial past and the rest of the urban fabric.

While both Lodz and Lyon have in their centers areas of dense metropolitan development, the down-town sites of Lodz are affected by many problems that are not observed in Lyon. What also makes Lyon different from Lodz is its landscape values - its urban fabric shaped by two rivers and hills is more attractive. They are still considered an asset by the present-day urban planners and are used to enhance public spaces (e.g. such the river boulevards).

Both Lyon and Lodz have large historically significant areas that are "traditional" in terms of layout (the grid of streets, parcels within blocks) and architecturally (the spaces of streets, squares, and entire blocks are defined by building facades). Public and private spaces are easily distinguishable from each other in both cities, but in Lodz there is a slight disproportion between them.
Given that the extent of changes that can be made to spatial order in urban areas is defined by the law in force, future research studying the New Urbanist principles in the context of urban regeneration projects should consider the Schuyler's question about whether "the principles [...] can be integrated into local planning and building codes" (Schuyler, 1997, p. 353). The implementation of the principles can be a special challenge for cities with substantial post-industrial heritage that need to transform it to make better and more rational use of their land.

\section{BIBLIOGRAPHY}

Alexander, Ch., Ishikawa, S., Silverstein, M., Jacobson, M., Fiksdahl-King, I., Shlomo, A. (1977). A pattern language: towns, buildings, construction. New York: Oxford University Press.

Alexander, Ch., Neis, H., Anninou, A., King, I. (1987). A new theory of urban design. New York: Oxford University Press.

Alidoust, S., Bosman, C., Holden, G. (2018). Talking while walking: an investigation of perceived neighbourhood walkability and its implications for the social life of older people. Journal of Housing and the Built Environment, 33 (1), pp. 133-150.

Amin, A., Thrift, N. (2002). Cities. Reimagining the urban. Cambridge: Polity Press.

Appleyard, D., Lintell, M. (1971). The environmental quality of city streets: The residents' viewpoint. Journal of the American Institute of Planners, 38 (2), pp. 84-101.

Bohl, C.C. (2000). New urbanism and the city: Potential applications and implications for distressed inner city neighbourhoods. Housing Policy Debate, 11 (4), pp. 761-802.

CABE Space (2004). The value of public space. London: Commission for Architecture and the Built Environment.

Calthorpe, P. (1993). The next American metropolis: Ecology, community and the American dream. New York: Princeton Architectural Press.

CNU - Congress for the New Urbanism (2001). Charter of the New Urbanism. The Congress for the New Urbanism, https:// www.cnu.org/sites/default/files/charter_english.pdf (accessed 9 March 2018).

Cysek-Pawlak, M.M., Krystkowski, T. (2018). Spatial planning policy and migration movements: A case study of Lodz. The International Journal of the Constructed Environment, 9 (1), pp. 19-35, http://dx.doi.org/10.18848/2154-8587/CGP/v09i01/

Davis, D., Duany, A., Plater-Zyberk, E. (1999). The lexicon of New Urbanisme. Miami: Duany Plater-Zyberk \& Company.

Duany, A., Talen, E. (2002). Transect planning. Journal of the American Planning Association, 68 (3), pp. 245-266; http://dx. doi.org/10.1080/01944360208976271

Dzieciuchowicz, J. (1984). Problemy demograficzne śródmieścia, Acta Universitatis Lodziensis. Folia Geographica, 3, pp. 37-67.

Dzieciuchowicz, J. (2009a). Ludność Łodzi od 1918 roku do lat 90. XX wieku. In: S. Liszewski, K. Badziak (eds), Łódź: monografia miasta (pp. 265-296). Łódź: Łódzkie Towarzystwo Naukowe.

Dzieciuchowicz, J. (2009b). Przemiany ludnościowe Łodzi na przełomie XX i XXI wieku. Prognoza demograficzna Łodzi. In: S. Liszewski, K. Badziak (eds), Łódź: monografia miasta (pp. 381-399). Łódź: Łódzkie Towarzystwo Naukowe. 
Dzieciuchowicz, J. (2011). Środowisko mieszkaniowe wielkiego miasta. Przyktad Łodzi. Łódź: Wydawnictwo Uniwersytetu Łódzkiego.

Dzieciuchowicz, J. (2014). Ludność Łodzi - rozwój i przemiany strukturalne. Łódź: Wydawnictwo Uniwersytetu Łódzkiego.

ECTP-CEU - European Council of Town Planners (2003). The New Charter of Athens 2003. Lisbon: European Council of Town Planners.

Ellis, C. (2002). The new urbanism: Critiques and rebuttals. Journal of Urban Design, 7 (3), pp. 261-291; http://dx.doi.org/10.1080/ 1357480022000039330

Fainstein, S.S. (2000). New directions in planning theory. Urban Affairs Review, 35 (4), pp. 451-478.

Farr, D.D. (2008). Sustainable urbanism: Urban design with nature. Hoboken: Wiley.

Foster, S., Hopper, P., Knuiman, M., Bull, F., Giles-Corti, B. (2016). Are liveable neighbourhoods safer neighbourhoods? Testing the rhetoric on new urbanism and safety from crime in Perth, Western Australia. Social Science \& Medicine, 164, pp. 150-157.

Gallimore, J.M., Brown, B.B., Werner, C.M. (2011). Walking routes to school in New Urban and suburban neighbourhoods: An environmental walkability analysis of blocks and routes. Journal of Environmental Psychology, 31 (2), pp. 184-191.

Hebbert, M. (2003). The movement in the context. Built Environment, 29 (3), pp. 193-209.

Janiszewska, A., Klima, E., Rochmińska, A. (2011). Centra handlowe w Łodzi - zawłaszczona przestrzeń publiczna? In: I. Jażdżewska (ed.), Człowiek w przestrzeni publicznej miasta (pp. 157-166). Łódź: Wydawnictwo Uniwersytetu Łódzkiego.

Kaniewicz, S., Nowakowska, B., Wosiak, A. (2002). Plansza XIV Rozwój i rozmieszczenie ludności. In: S. Liszewski (ed.), Atlas miasta Łodzi. Łódź: Łódzkie Towarzystwo Naukowe.

Katz, P. (1994). The new urbanism: Toward an architecture of community. New York: McGraw-Hill.

Kazimierczak, J. (2014). Wptyw rewitalizacji obszarów poprzemystowych na organizacje przestrzeni centralnej w Manchesterze, Lyonie $i$ Łodzi. Łódź: Wydawnictwo Uniwersytetu Łódzkiego.

Koter, M. (1969). Geneza uktadu przestrzennego Łodzi przemysłowej. Warszawa: Państwowe Wydawnictwo Naukowe.

Koter, M. (2009). Tkanka miejska Łodzi w latach 1918-1989. In: S. Liszewski, K. Badziak (eds), Łódź: monografia miasta (pp. 218-264). Łódź: Łódzkie Towarzystwo Naukowe.

Krier, L. (2009). The architecture of community. Washington: Island Press.

Leccese, M., McCormick, K. (2000). Congress for the New Urbanism. New York: McGraw-Hill.

Lynch, K. (1960). The image of the city. Cambridge: The Technology Press \& Harvard University Press.

Marshall, S. (2003). New urbanism: An introduction. Built Environment, 29 (3), pp. 189-192.

Mordwa, S. (1993). Wyobrażenia przestrzeni miejskiej Łodzi. Kronika Miasta Łodzi, 3 (2): 69-80.

MPU - Miejska Pracownia Urbanistyczna [Lodz Municipal Urban Planning Office] (2018). Studium uwarunkowań i kierunków zagospodarowania przestrzennego miasta Łodzi. Uwarunkowania. [Study of conditions and directions of spatial development of the city of Lodz. Conditions]. Łódź: Miejska Pracownia Urbanistyczna.

Neuman, M. (2005). The compact city fallacy. Journal of Planning Education and Research, 25 (1), pp. 11-26, http://dx.doi.org/ 10.1177/07394 56X04270466

Newman, P. (1996). Formes de la ville et transports: vers un nouvel urbanisme. Cahiers de l'Institut d'Amenagement et d'Urbanisme de la Region d'Ile-de-France, 114-115, pp. 98-109.

Orłowski, T.H. (1984). Elementy planowania urbanistycznego Łodzi w latach 1860-1914. Miscellanea Łódzkie, 1, pp. 83-108.
Ostrowski, W. (1996). Wprowadzenie do historii budowy miast. Ludzie $i$ środowisko. Warszawa: Oficyna Wydawnicza Politechniki Warszawskiej.

Piątek, G. (2006). Manufaktura w Łodzi. Adaptacja XIX-wiecznej fabryki na centrum handlowe. Architektura Murator, 10 (145), pp. 46-55.

Piatkowski, D., Marshall, W. (2014). 'New' versus 'old' urbanism: a comparative analysis of travel behaviour in large-scale New Urbanist communities and older, more established neighbourhoods in Denver, Colorado. Urban Design International, 19 (3), pp. 228-245; http://dx.doi.org/10.1057/ udi.2013.30

Plaut, P.O., Boarnet, M.G. (2003). New Urbanism and the value of neighbourhood design. Journal of Architectural and Planning Research, 20 (3), pp. 254-265.

Rodríguez, D.A., Khattak, A.J., Evenson, K.R. (2007). Can New Urbanism encourage physical activity? Comparing a new urbanist neighbourhood with conventional suburbs. Journal of the American Planning Association, 72 (1), pp. 43-54; http:/ / dx.doi.org/10.1080/01944360608976723

Rykwert, J. (2013). Pokusa miejsca. Przeszłość i przyszłość miast. Kraków: Międzynarodowe Centrum Kultury.

Schuyler, D. (1997). The new urbanism and the modern metropolis. Urban History, 24, pp. 344-358.

Suliborski, A., Dmochowska-Dudek, K. (2014). Dysproporcje w zagospodarowaniu przestrzeni miejskiej Łodzi - uwarunkowania genetyczno-funkcjonalne. In: A. Suliborski, M. Wójcik (eds). Dysproporcje społeczne $i$ gospodarcze w przestrzeni Łodzi. Czynniki, mechanizmy, skutki (pp. 77-106). Łódź: Wydawnictwo Uniwersytetu Łódzkiego.

Talen, E. (1997). Sense of community and neighbourhood form: An assessment of the social doctrine of New Urbanism. Urban Studies, 36 (8), pp. 1361-1379; http://dx.doi.org/10. $1080 / 0042098993033$

Talen, E. (2000). Measuring the public realm: A preliminary assessment of the link between public space and sense of community. Journal of Architectural and Planning Research, 17 (4), pp. 344-360.

Tobiasz-Lis, P. (2008). Wyobrażenia kobiet i mężczyzn o przestrzeni Łodzi, Acta Universitatis Lodziensis. Folia Geographica Socio-Oeconomica, 8 (9), pp. 147-162.

Tobiasz-Lis, P. (2014). Wpływ procesu gentryfikacji na dysproporcje w centrum Łodzi. In: A. Suliborski, M. Wójcik (eds), Dysproporcje społeczne i gospodarcze w przestrzeni Łodzi. Czynniki, mechanizmy, skutki (pp. 171-186). Łódź: Wydawnictwo Uniwersytetu Łódzkiego.

Trudeau, D. (2013). A typology of New Urbanism neighbourhoods. Journal of Urbanism International Research on Placemaking and Urban Sustainability, 6 (2), pp. 113-138; http:/ / dx. doi.org/10.1080/17549175.2013.771695

Trudeau, D., Kaplan, J. (2015). Is there diversity in the New Urbanism? Analyzing the demographic characteristics of New Urbanist neighbourhoods in the United States. Urban Geography, 37 (3), pp. 458-482; http://dx.doi.org/10.1080/ 02723638.2015.1069029

UMŁ - Urząd Miasta Łodzi [Lodz City Hall] (2013). Strategia przestrzennego rozwoju Łodzi 2020+. Załącznik do uchwały nr LV/1146/13 Rady Miejskiej w Łodzi [Strategy for Spatial Development of Lodz 2020+. Lodz City Council resolution no. LV/1146/13], http://uml.lodz.pl/miasto/ strategia/, accessed 5 March 2017.

Unesco (1998). City of Lyon. Application dossier for registration of the historic site of Lyon on the world heritage list. Volume I. WHC Nomination Documentation, 12 December, https:/ / whc.unesco.org/uploads/nominations/872.pdf 
Wiśniewski, M. (1984). Konsekwencje dziewiętnastowiecznego rozwoju przestrzennego w planowaniu przekształceń śródmieścia Łodzi, Kwartalnik Architektury $i$ Urbanistyki XXIX (1-2), pp. 113-136.

Wiśniewska, W. (2009). Przebudowa przestrzenna i funkcjonalna Łodzi po 1989 roku. In: S. Liszewski, K. Badziak (eds) Łódź: monografia miasta (pp. 432-482). Łódź: Łódzkie Towarzystwo Naukowe.

Wolaniuk, A. (2002a). Plansza XXXVII: Rozwój funkcji metropolitalnych Łodzi. In: S. Liszewski (ed.), Atlas miasta Łodzi. Łódź: Łódzkie Towarzystwo Naukowe.

Wolaniuk, A. (2002b). Plansza XXXVIII: Rozmieszczenie i struktura instytucji metropolitalnych Łodzi w 2000 roku. In: S. Liszewski (ed.) Atlas miasta Łodzi. Łódź: Łódzkie Towarzystwo Naukowe.
Wójcik, M. (2009). Centrum handlowo-rozrywkowe jako „miejsce” w przestrzeni społecznej Łodzi. Przykład „Manufaktury", Space - Society - Economy, 9, pp. 133-142.

Wójcik, M. (2010). Centrum handlowo-rozrywkowe Manufaktura jako „miejsce” integrujące w przestrzeni społecznej Łodzi. In: A. Suliborski, Z. Przygodzki (eds) Łódzka metropolia. Problemy integracji spotecznej i przestrzennej (pp. 41-50). Łódź: Wydawnictwo Biblioteka.

Wójcik, M., Tobiasz-Lis, P. (2014). Ocena przestrzennych dysproporcji w Łodzi z perspektywy mieszkańców miasta. In: A. Suliborski, M. Wójcik (eds), Dysproporcje społeczne i gospodarcze w przestrzeni Łodzi. Czynniki, mechanizmy, skutki (pp. 305-320). Łódź: Wydawnictwo Uniwersytetu Łódzkiego.

Artykuł wpłyną 3 listopada 2019 Zaakceptowano do druku: 28 grudnia 2019 